\title{
METABOLIC DISTURBANCES IN EXPERIMENTAL HUMAN VITAMIN B DEFICIENCY
}

\author{
By K. O'SHEA ELSOM, FRANCIS D. W. LUKENS, ESTHER H. MONTGOMERY, \\ AND LEON JONAS ${ }^{1}$ \\ (From the Gastro-Intestinal Section (Kinsey-Thomas Foundation) of the Medical Clinic, the \\ George S. Cox Medical Research Institute and the William Pepper Laboratory of \\ Clinical Medicine, University Hospital, and the Department of Physio- \\ logical Chemistry, Medical School, University of \\ Pennsylvania, Philadelphia)
}

(Received for publication August 30, 1939)

Recent animal experiments have indicated that the vitamin B complex is necessary for the normal metabolism of carbohydrate. The abnormality most frequently reported in vitamin $B_{1}$ deficiency is an interference with some phase of the oxidation of carbohydrate, so that intermediary products of glucose metabolism accumulate in the tissues $(1,2,3,4,5)$ and in the blood (6), while tissue oxidation decreases. The substances most commonly observed to accumulate are lactic acid, pyruvic acid and certain as yet unidentified compounds which have in common the ability to bind bisulphite. Many other phenomena are reported with far less consistency in animals deficient in various members of the $B$ complex, such as the occurrence of hyperglycemia (7), ketonuria and interference with the storage of glycogen in the liver $(8,9,10)$, decrease in the respiratory quotient (11), sensitivity to insulin (12), etc. The application to man of the knowledge gained from these animal experiments must, however, be made cautiously for several reasons. Different species of laboratory animals vary greatly in their requirements for the vitamin B group, so that it is uncertain in how far particular data obtained from animals are transferable to man. The animal experiments have furthermore been performed under specialized laboratory conditions which permit the study of one or more isolated members of the vitamin B complex. Although this form of study provides important data concerning the function of separate fractions of the $B$ complex, it has recently been shown that deficiency of one fraction so modifies the manifestations of deficiency due to other members of the group (13) that the effects of combined deficiencies cannot justifiably be assumed from

1 Woodward Fellow in Physiological Chemistry. study of isolated fractions. It is probable that such experiments fail to give accurate information concerning the complex conditions of multiple deficiency observed in man. Unfortunately, the study of fully developed human deficiency as seen in the clinic is unsatisfactory because the exact nature and extent of the deficiency cannot be determined with accuracy, and unknown factors undoubtedly influence the phenomena under consideration. If the problem, as applied to man, is to be clarified, it seems desirable that studies be made directly upon human beings living under controlled conditions of vitamin B deficiency ${ }^{2}$ in whom the influence of deficiency of the B complex as a whole may be compared with effects of deficiency of the separate fractions. The present paper is a report of such a study made upon one individual who voluntarily consumed for a period of 4 months a constant diet deficient only in the $\mathrm{B}$ complex. The fact that this woman consumed a constant amount of food throughout observation permitted a more accurate study of the effects of deficiency of the $B$ complex alone than is often possible in animal experiments where anorexia results in diminished food intake and the introduction of complicating deficiencies. After signs of deficiency had developed, thiamin, riboflavin and brewer's yeast were added to the diet in series as shown in Figure 1 and their effects were studied. These studies dealt chiefly with carbohydrate metabolism and included the determination of the response of the organism to the administration of glucose as measured by blood sugar and respiratory quotient, the response to a standard dose of insulin, and

2 The term vitamin B as used occasionally in this paper refers to the $B$ complex as a whole. Individual members of the complex are designated separately. 


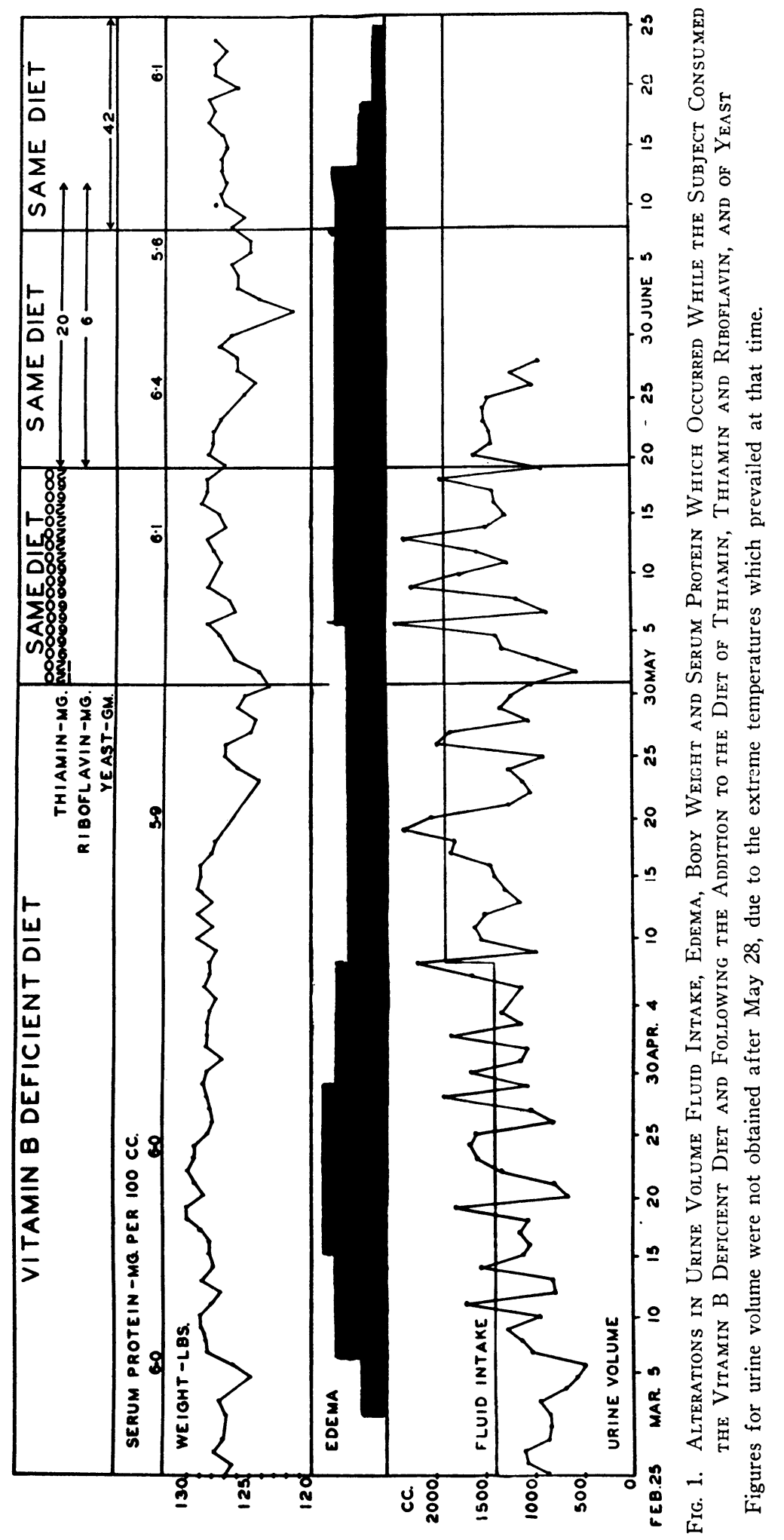


estimations of blood pyruvic acid, lactic acid and bisulphite-binding substances before and after the ingestion of glucose. In addition, studies were made of serum protein and alteration in weight and fluid balance.

\section{METHODS OF STUDY}

The subject, a healthy woman aged 60 , who had served in a previous study (14) of vitamin B deficiency, volunteered to consume a diet deficient in the vitamin B complex. The observations were made in the metabolic ward of the University of Pennsylvania Hospital from February 25 to June 25, 1938, during which time she consumed daily the experimental diet outlined in Table I. The articles of diet, in the quantities indicated, supplied protein, fat, carbohydrate and total calories in optimal amounts. The vitamin $B_{1}$ content of the diet was about one-third of her calculated minimal requirement.

The vitamin $B_{1}$ of the diet is expressed in milligram equivalents, i.e., the amount of vitamin $B_{1}$ in each food which is equivalent in terms of biological assay to a corresponding number of milligrams of a standard yeast powder. The theoretical minimal requirement of vitamin

TABLE I

Composition of the deficient diet and its supplements (per day)

\begin{tabular}{|c|c|c|c|c|c|c|}
\hline \multirow[t]{2}{*}{ Food } & Weight & $\begin{array}{l}\text { Pro- } \\
\text { tein }\end{array}$ & Fat & $\begin{array}{l}\text { Carbo- } \\
\text { hydrate }\end{array}$ & $=\begin{array}{l}\text { Cal- } \\
\text { ories }\end{array}$ & $\begin{array}{l}\text { Vita- } \\
\text { min } B_{1}\end{array}$ \\
\hline & grams & grams & grams & grams & & mgm.* \\
\hline \multicolumn{7}{|c|}{ FOODS } \\
\hline 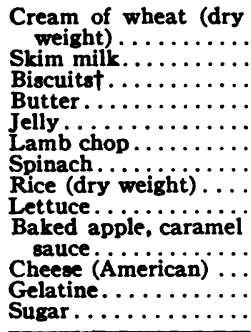 & $\begin{array}{c}32 \\
25 \\
323 \dagger \\
20 \\
72 \\
20 \\
25 \\
32 \\
25 \\
75 \\
20 \\
17 \\
100\end{array}$ & $\begin{array}{l}6 \\
1 \\
21 \\
3 \\
5 \\
0.5 \\
3 \\
1 \\
5 \\
4 \\
16.5\end{array}$ & $\begin{array}{r}39 \\
16 \\
4\end{array}$ & $\begin{array}{r}24 \\
1 \\
146 \\
48 \\
2 \\
24 \\
\\
37 \\
25 \\
100\end{array}$ & $\begin{array}{r}110 \\
8 \\
1020 \\
144 \\
219 \\
56 \\
10 \\
108 \\
4 \\
231 \\
70 \\
166 \\
400\end{array}$ & $\begin{array}{r}96 \\
55 \\
510 \\
128 \\
\\
200 \\
50 \\
51 \\
50 \\
150 \\
40\end{array}$ \\
\hline Total.......... & & 66 & 72 & 408 & 2544 & 1330 \\
\hline \multicolumn{7}{|c|}{ FOOD SUPPLEMENTS } \\
\hline 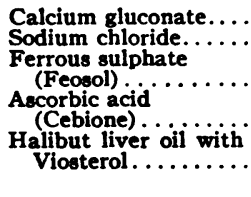 & $\begin{array}{c}3 \\
5 \\
0.6 \\
0.1 \\
2 \text { cap- } \\
\text { sules }\end{array}$ & & & & $\cdot$ & \\
\hline
\end{tabular}

* See text.

$\dagger$ Recipe for biscuits:

Flour........... 170 grams

Lard ............. 38 grams Weight of recipe

Baking powder..... 2 tsp. 323 grams.
$B_{1}$ of this individual was calculated from the formula of Cowgill (15):

$$
V I T_{i}=K_{8} \cdot W_{i} \cdot C A L_{i},
$$

where $V I T_{i}$ is the vitamin (in milligram equivalents) required daily by an individual whose body weight, $W_{i}$, is expressed in grams. $C A L_{i}$ (kilogram calories) represents the total daily energy exchange, for which the calculated caloric value of the diet (2544 calories) has been used. $K_{8}$ is a species constant which, for man, Cowgill has determined to be 0.0000284 . The vitamin $B_{1}$ requirement of this subject, whose initial weight was 58.5 kilograms, was found to be $4225 \mathrm{mgm}$. eq. per day.

It was assumed that the amounts of other members of the $\mathrm{B}$ complex were proportionately decreased in the diet. Vitamins $\mathrm{A}, \mathrm{C}$ and $\mathrm{D}$, iron, calcium and sodium chloride in amounts thought to be optimal supplemented the diet as indicated in Table I. Except for days when experimental procedures required that food be withheld and for one 5-day period, beginning April 18, when abdominal symptoms suggestive of appendicitis made a marked reduction of the diet advisable, the intake of food and food supplements was constant from the time of admission to discharge. The loss of weight during the period of low food intake (April 18-20) is explained by the decrease in the diet. Daily fluid intake, as made up by the liquid components of the diet, was 1400 cc. until April 8, when it was increased to $1900 \mathrm{cc}$. The term "fluid balance" as used in the text refers to the relation of fluid intake to urine volume.

The experimental regimen, divided into the 5 following consecutive periods, was begun immediately on admission to the hospital: (1) the first week on the deficient diet, called "first period" in the tables, which was regarded as a control period; (2) the subsequent 8 weeks on the same diet, during which time signs of deficiency appeared (this period was terminated because of the development of clinical manifestations of deficiency demanding treatment) ${ }^{3}$; (3) a period of 18 days during which thiamin hydrochloride 4 alone was added to the deficient diet in doses ranging from 20 to 120 milligrams daily; (4) 20 days during which riboflavin was administered, 6 milligrams daily, in addition to thiamin; (5) the final 18 days when brewer's yeast ${ }^{5}$ was given, 42 grams daily. This period was shorter than desired due to unavoidable circumstances, so that the effects of this therapeutic agent were

${ }^{3}$ The clinical manifestations of deficiency which were observed, together with clinical studies made upon the subject during each experimental period, will be reported in a separate communication.

4 This material (as Betabion) and the riboflavin were supplied through the courtesy of Mr. P. C. Ackerman of Merck and Company.

${ }^{5}$ The brewer's yeast was kindly supplied by Dr. J. H. Harris of the Harris Laboratories, Tuckahoe, New York, as "Brewer's Yeast-Harris Medicinal Powder." Our analysis showed that its nitrogen content was 7.8 per cent. By the usual calculation $(\mathrm{N} \times 6.25)$ this supplied 21 grams of protein in addition to that of the diet. 
evident but probably not maximal before it was necessary for the subject to leave the hospital.

The subject was weighed daily under standard conditions. Total output of urine was recorded daily. Total serum protein was determined occasionally. Fasting blood sugar determinations and sugar tolerance tests were carried out several times in each period. Venous blood sugar, as true blood sugar, was determined before and at hourly intervals for 4 hours after the ingestion of 100 grams of glucose. The blood sugar was determined by the micro method of Folin and Malmros (16) modified for use with the Evelyn photoelectric colorimeter (17). Urine, collected before and at hourly intervals throughout the test, was analyzed qualitatively for sugar and ketones. The respiratory quotient was determined, using the Tissot apparatus, before each sugar tolerance test and hourly for 3 to 4 hours after the glucose had been given. Blood lactic acid was determined by the method of Friedemann and Graeser (18), pyruvic acid by the method of Wendel (19). Bisulphite-binding substances in the blood were determined by a slight modification of the method of Clift and Cook (20). These analyses were made upon the fasting subject at various times during observation and at 1,2 and 4 hours following the administration of 100 grams of glucose. The response to insulin was studied under basal conditions at various times during each experimental period, 2.5 units of insulin being given subcutaneously in each test. Blood and urine samples were obtained prior to giving the insulin and at 1/2, 1, 2 and 3 hours thereafter.

\section{RESULTS}

\section{Alterations in weight and fluid balance}

Changes in weight at first corresponded to alterations in fluid balance but late in deficiency the subject lost weight in spite of fluid retention (Figure 1). The 24-hour urinary nitrogen excretion was determined for 3 days of each experimental period. Table II shows these nitrogen values as well as the 24-hour urine volumes.

Edema appeared 5 days after the diet was begun. As in earlier studies of vitamin B deficiency (14) no adequate explanation for its occurrence is available. Alterations in serum protein were not sufficient to account for it. Previous attempts to demonstrate increased capillary permeability or increased capillary pressure yielded negative results, and were not repeated during this study. Periods of fluid retention and periods of fluid loss began and terminated suddenly without known change in the subject's environment. From the 10th to the 50th day of observation variations in edema and in fluid balance could account for the observed fluctuations in weight.
TABLE II

Daily urine volume and urine nitrogen during the experimental periods

\begin{tabular}{|c|c|c|c|}
\hline $\begin{array}{l}\text { Date } \\
1938\end{array}$ & $\begin{array}{c}\text { Urine } \\
\text { volume }\end{array}$ & $\begin{array}{c}\text { Urine } \\
\text { nitrogen }\end{array}$ & Period \\
\hline $\begin{array}{l}\text { Feb. } 27 \ldots \ldots \\
\text { March } 1 \ldots \ldots \\
\text { March } 3 \ldots \ldots\end{array}$ & $\begin{array}{c}c c . \text { per } \\
\text { day } \\
1102 \\
1105 \\
944\end{array}$ & $\begin{array}{c}\text { grams } \\
\text { per day } \\
4.5 \\
4.4 \\
6.7\end{array}$ & First period \\
\hline $\begin{array}{l}\text { April } 27 \ldots \ldots \\
\text { April } 28 \ldots \ldots \\
\text { April } 29 . \ldots \ldots\end{array}$ & $\begin{array}{l}1883 \\
1063 \\
1389\end{array}$ & $\begin{array}{l}3.3 \\
3.1 \\
4.2\end{array}$ & $\begin{array}{l}\text { Vitamin B-deficient diet } \\
\text { (9th week) }\end{array}$ \\
\hline $\begin{array}{l}\text { May } 17 \ldots \ldots \\
\text { May } 18 \ldots \ldots \\
\text { May } 19 \ldots \ldots\end{array}$ & $\begin{array}{r}1421 \\
1916 \\
899\end{array}$ & $\begin{array}{l}3.7 \\
3.0 \\
2.8\end{array}$ & Deficient diet + thiamin \\
\hline $\begin{array}{l}\text { June } 3 \ldots \ldots \\
\text { June } 4 \ldots \ldots \\
\text { June } 5 \ldots \ldots\end{array}$ & $\begin{array}{r}828 \\
1578 \\
1720\end{array}$ & $\begin{array}{l}5.1 \\
4.2 \\
4.1\end{array}$ & $\begin{array}{l}\text { Deficient diet }+ \text { thiamin } \\
+ \text { riboflavin }\end{array}$ \\
\hline $\begin{array}{l}\text { June } 17 \ldots \ldots \\
\text { June } 18 \ldots \ldots \\
\text { June } 21 \ldots \ldots\end{array}$ & $\begin{array}{r}1992 \\
1270 \\
774\end{array}$ & $\begin{array}{l}7.6 \\
6.7 \\
7.1\end{array}$ & Deficient diet + yeast \\
\hline
\end{tabular}

After 50 days on the diet, the weight declined coincident with the temporarily restricted diet. It rose when the full diet was resumed but did not return to the previous level and it fell again before thiamin was given. The weight was restored by thiamin. The sharp, temporary fall during the riboflavin period accompanied a fasting day on May 31. However, the maintenance of weight during the yeast period, at a time when edema was subsiding, suggests that yeast may contain some factor or factors, other than thiamin and riboflavin, which control the regulation of body fluid and perhaps the building of body tissues.

\section{Blood sugar and respiratory quotient following glucose}

The blood sugar concentration was determined at hourly intervals after the oral administration of glucose in each experimental period (Table III). During the first period and upon the initial examination in the period of deficiency the values are within the normal range for glucose tolerance curves. Likewise, the rise in blood sugar during the first and second hours following the administration of glucose was within normal limits throughout all periods of observation. However, beginning late in deficiency (April 18) and continuing until after 12 days of administra- 
TABLE III

Blood sugar, fasting and following the oral administration of 100 grams of glucose in the different experimental periods

\begin{tabular}{|c|c|c|c|c|c|c|}
\hline \multirow{2}{*}{$\begin{array}{l}\text { Date } \\
1938\end{array}$} & \multicolumn{5}{|c|}{ Blood sugar } & \\
\hline & $\begin{array}{c}\text { Fast- } \\
\text { ing }\end{array}$ & $\begin{array}{c}1 \\
\text { hour }\end{array}$ & $\begin{array}{c}2 \\
\text { hours }\end{array}$ & $\begin{array}{c}3 \\
\text { hours }\end{array}$ & $\begin{array}{c}4 \\
\text { hours }\end{array}$ & \\
\hline March 1 & $\begin{array}{l}\text { mgm. } \\
\text { per } \\
100 \\
c c . \\
92\end{array}$ & $\begin{array}{c}\underset{\text { mgm. }}{\text { per }} \\
100 \\
c c . \\
174\end{array}$ & $\begin{array}{c}\text { mgm. } \\
\text { per } \\
100 \\
c c . \\
145\end{array}$ & $\begin{array}{c}\text { mgm. } \\
\text { per } \\
100 \\
c c . \\
126\end{array}$ & $\begin{array}{c}\underset{\text { mgm. }}{\text { per }} \\
100 \\
c c . \\
85\end{array}$ & \multirow{2}{*}{ First period } \\
\hline March 4 & 70 & 135 & 150 & 132 & 93 & \\
\hline March 23 & 63 & 108 & 127 & 88 & 80 & \multirow{3}{*}{ Deficient diet } \\
\hline April 5 & 69 & 155 & 121 & 119 & & \\
\hline April 18 & 61 & 124 & 116 & 138 & 108 & \\
\hline May 4 & 74 & 148 & 145 & 155 & 153 & \multirow{2}{*}{$\begin{array}{l}\text { Deficient diet } \\
+ \text { thiamin }\end{array}$} \\
\hline May 10 & 80 & 152 & 159 & 143 & 122 & \\
\hline May 23 & 85 & 145 & 146 & 124 & 137 & \multirow{2}{*}{$\begin{array}{c}\text { Deficient diet } \\
\text { + thiamin } \\
\text { + riboflavin }\end{array}$} \\
\hline June 6 & 73 & 140 & 151 & 142 & 132 & \\
\hline June 15 & 73 & 158 & 160 & 136 & 130 & \multirow{2}{*}{$\begin{array}{l}\text { Deficient diet } \\
+ \text { yeast }\end{array}$} \\
\hline June 20 & 65 & 139 & 115 & 101 & 89 & \\
\hline
\end{tabular}

tion of yeast (June 20), the 4th-hour blood sugar values failed to return to near the fasting value. These 4th-hour sugars exceeded the fasting values by 47 to 79 milligrams per cent, while during the control period and following the administration of yeast the maximum elevation over the fasting value at 4 hours was 24 milligrams per cent. At the same time that the 4th-hour values were elevated the 3rd-hour values tended to exceed those obtained during the first period and after yeast. The urine at no time contained sugar or ketone bodies. Since the peak of the blood sugar curve after glucose was not significantly altered, it was assumed that the absorption of glucose from the gastro-intestinal tract was not impaired. This conclusion was borne out also by a single measurement of the absorption of glucose from the small intestine during deficiency, ${ }^{6}$ using the MillerAbbott tube (21) and employing a modification of the method of Groen (22) which gave a result within the normal range. The removal of glucose from the blood stream, however, appeared to be diminished as judged by the 3rd- and 4th-hour

- We are indebted to Dr. Paul M. Glenn and Dr. Olive D. Hoffman for the performance of this experiment. blood sugar figures. This defect became definite late in deficiency, was unaffected either by thiamin or riboflavin, but disappeared following the administration of yeast. A reasonable explanation for these variations is that interference with glycogen deposition in the liver had occurred. Impaired glycogenesis in the liver following the parenteral administration of glucose has been demonstrated in animals deficient in the B complex $(8,9,10)$. Whatever the mechanism may be, thiamin and riboflavin were without effect upon the glucose tolerance curve while yeast appeared to restore the ability to utilize carbohydrate normally.

It is of considerable interest that the findings relative to blood sugar, observed in this subject during deficiency, are comparable to the changes of early inanition (23) and also to the changes recently described in liver disease (24). In $B_{1}$ deficiency in animals hyperglycemia (7), glycosuria and the appearance of ketone bodies in the urine have been reported, suggesting a diabeticlike state. In human diabetics the administration of vitamin $B_{1}$ was thought to have resulted in an improved sugar tolerance (25). However, nothing to suggest a diabetic tendency was observed in the present subject either during partial deficiency or following the administration of thiamin or riboflavin.

Throughout the periods of deficiency and therapy the basal metabolic rate ranged from -12 to +5 , the average being -8 per cent.

Disturbances in the respiratory quotient following the administration of glucose to animals both during $B_{1}$ deficiency and after the administration of thiamin have been reported (11). Our findings (Table IV) show no significant variations in the fasting respiratory quotient, and the response of the quotient to glucose appeared normal at all times.

\section{Blood bisulphite-binding substances, pyruvic and lactic acid}

During the course of the experiment, weekly fasting values for total bisulphite-binding substances, lactic acid and pyruvic acid were obtained on protein- and sugar-free filtrates. During the glucose tolerance tests these substances were determined also at intervals of approximately 1 or 2 and 4 hours after the ingestion of glucose. 
TABLE IV

Respiratory quotient, fasting and following the oral administration of 100 grams of glucose in the different experimental periods

\begin{tabular}{|c|c|c|c|c|c|c|}
\hline $\begin{array}{l}\text { Date } \\
1938\end{array}$ & $\begin{array}{c}\text { Fast- } \\
\text { ing }\end{array}$ & $\begin{array}{c}1 \\
\text { hour }\end{array}$ & $\stackrel{2}{2}$ & $\stackrel{3}{\text { hours }}$ & hours & \\
\hline March 1 & & 0.90 & 0.94 & 0.98 & 0.97 & \multirow{2}{*}{ First period } \\
\hline March 4 & 0.75 & 0.83 & 0.95 & 0.98 & 0.98 & \\
\hline March 23 & 0.91 & 0.89 & 0.96 & 0.94 & 0.93 & \multirow{3}{*}{ Deficient diet } \\
\hline April 5 & 0.87 & 1.00 & 0.97 & 0.99 & & \\
\hline April 18 & 0.79 & 0.92 & 0.88 & 0.92 & & \\
\hline May 4 & 0.78 & 0.94 & 0.91 & 0.97 & & \multirow{2}{*}{$\begin{array}{c}\text { Deficient diet } \\
\text { + thiamin }\end{array}$} \\
\hline May 10 & 0.78 & 0.89 & 0.94 & 0.90 & & \\
\hline May 23 & 0.88 & 0.95 & 0.91 & 0.94 & 0.89 & \multirow{2}{*}{$\begin{array}{c}\text { Deficient diet } \\
\text { + thiamin } \\
\text { + riboflavin }\end{array}$} \\
\hline June 6 & 0.81 & 0.94 & 0.91 & 0.92 & 0.98 & \\
\hline June 15 & 0.83 & 0.88 & 0.94 & 0.92 & 0.92 & \multirow{2}{*}{$\begin{array}{l}\text { Deficient diet } \\
\text { + yeast }\end{array}$} \\
\hline June 20 & 0.88 & 0.96 & 0.96 & & 0.95 & \\
\hline
\end{tabular}

Table $\mathrm{V}$ gives the values obtained. The fasting bisulphite-binding power did not rise during the period of vitamin B deficiency nor were the values significantly elevated after glucose. Taylor, Weiss and Wilkins (26), as well as Platt and Lu (27), obtained elevated values for bisulphite-binding substances in fasting subjects with clinical vitamin B deficiency. Two explanations for the difference between our results and theirs may be considered: either that in our subject the deficiency did not proceed to such an advanced stage as to give this change, or that the clinical deficiencies studied were complicated by inanition or by deficiencies other than vitamin B. Inanition has been shown by Lipschitz and co-workers (28) to be responsible for a large part of the disturbances noted in the carbohydrate metabolism of vitamin B-deficient animals.

Pyruvic acid concentrations in the fasting blood of the subject were not increased during the period of vitamin B deficiency. However, after

TABLE $\mathbf{V}$

Bisulphite-binding substances, lactic acid and pyruvic acid, fasting and following the oral administration of 100 grams of glucose in the different experimental periods

\begin{tabular}{|c|c|c|c|c|c|c|c|c|c|c|}
\hline \multirow{2}{*}{ Date } & \multicolumn{3}{|c|}{ B.B.S.* } & \multicolumn{3}{|c|}{ Lactic acid } & \multicolumn{3}{|c|}{ Pyruvic acid } & \\
\hline & Fasting & $\begin{array}{c}1 \text { hour } \\
\text { after } \\
\text { glucose }\end{array}$ & $\begin{array}{l}4 \text { hours } \\
\text { after } \\
\text { glucose }\end{array}$ & Fasting & $\begin{array}{l}1 \text { hour } \\
\text { after } \\
\text { glucose }\end{array}$ & $\begin{array}{l}4 \text { hours } \\
\text { after } \\
\text { glucose }\end{array}$ & Fasting & $\begin{array}{l}1 \text { hour } \\
\text { after } \\
\text { glucose }\end{array}$ & $\begin{array}{l}4 \text { hours } \\
\text { after } \\
\text { glucose }\end{array}$ & \\
\hline March $1 \ldots \ldots \ldots \ldots$ & $\begin{array}{c}\underset{m g m .}{m} . \\
\text { per } \\
100 \mathrm{cc} . \\
5.9\end{array}$ & 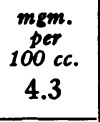 & $\begin{array}{c}\underset{\text { mgm. }}{\text { per }} \\
100 \mathrm{cc.} \\
4.1\end{array}$ & $\begin{array}{c}\underset{c k g m .}{\text { mger }} \\
100 \mathrm{cc.} \\
12.3\end{array}$ & $\begin{array}{l}\underset{c}{\operatorname{mem} .} \\
\text { per } \\
100 \mathrm{cc} . \\
17.7\end{array}$ & $\begin{array}{c}\text { mgm. } \\
\text { per } \\
100 \mathrm{cc} . \\
8.4\end{array}$ & $\begin{array}{c}\text { mgm. } \\
\text { per } \\
100 \mathrm{cc} . \\
1.7\end{array}$ & $\begin{array}{c}\underset{\text { mgm. }}{\text { per }} \\
100 \mathrm{cc.} \\
4.1\end{array}$ & 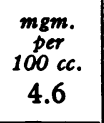 & \multirow{2}{*}{ First period } \\
\hline March $8 \ldots \ldots \ldots \ldots$ & 4.0 & & & 17.6 & & & 4.3 & & & \\
\hline March $15 \ldots \ldots \ldots \ldots$ & 4.1 & & & 17.3 & & & 3.2 & & & \multirow{5}{*}{ Deficient diet } \\
\hline March $22 \ldots \ldots \ldots \ldots$ & 4.5 & 4.7 & 4.8 & 27.1 & 17.6 & 13.2 & 4.6 & 5.9 & 0.6 & \\
\hline April $12 \ldots \ldots \ldots \ldots \ldots$ & 4.1 & 5.2 & 5.4 & 12.9 & $24.5 \dagger$ & 13.8 & 2.3 & 6.6 & 8.3 & \\
\hline April $18 \ldots \ldots \ldots \ldots$ & 5.6 & 8.2 & 8.5 & 10.1 & 21.2 & 19.8 & 4.1 & 11.6 & 8.1 & \\
\hline April $22 \ldots \ldots \ldots \ldots$ & 2.9 & & & 20.9 & & & 2.1 & & & \\
\hline May $4 \ldots \ldots \ldots \ldots$ & 3.6 & 5.0 & 2.5 & 15.7 & 22.5 & 19.8 & 1.3 & 5.1 & 1.4 & \multirow{2}{*}{$\begin{array}{l}\text { Deficient diet } \\
\text { + thiamin }\end{array}$} \\
\hline May $10 \ldots \ldots \ldots \ldots$ & 4.1 & 3.8 & 3.2 & 6.2 & 16.9 & 9.3 & 3.0 & 7.6 & 3.4 & \\
\hline May $24 \ldots \ldots \ldots \ldots$ & 2.3 & 4.9 & 1.8 & 7.0 & 18.9 & 7.5 & 0.1 & 6.8 & 1.5 & \multirow{2}{*}{$\begin{array}{l}\text { Deficient diet } \\
+ \text { thiamin }+ \\
\text { riboflavin }\end{array}$} \\
\hline May $31 \ldots \ldots \ldots \ldots$ & 3.1 & - & & 5.6 & & & 2.7 & & & \\
\hline June $20 \ldots \ldots \ldots \ldots$ & & 3.0 & 2.4 & & 15.5 & 10.0 & & 6.8 & 3.8 & \multirow{2}{*}{$\begin{array}{l}\text { Deficient diet } \\
+ \text { yeast }\end{array}$} \\
\hline June $23 \ldots \ldots \ldots \ldots$ & 4.8 & & & 11.5 & & & 0 & & & \\
\hline
\end{tabular}

* B.B.S. = Bisulphite binding substances.

† Two hours after glucose. 
glucose ingestion there was a rise in pyruvic acid, the values tending to remain elevated throughout the 4 hours of the test. Following the administration of thiamin, these 4th-hour values for pyruvic acid returned to within the normal fasting range.

Pyruvic acid, as determined by reduction to lactic acid, was always less than the total bisulphitebinding substances in the fasting blood of our subject, but it significantly exceeded bisulphite-binding substances after glucose ingestion. This discrepancy also occurred in 2 normal subjects and appeared greater than could readily be accounted for by the loss of some pyruvic acid from the filtrate before determination of bisulphite-binding power. Pyruvic acid contains a free carbonyl group which will quantitatively bind bisulphite. Since bisulphite-binding power did not rise concurrently with pyruvic acid there may be errors in one or both determinations by these methods.

The values for lactic acid of the blood appear to be elevated during deficiency both before and after glucose, particularly as compared with values obtained following the administration of thiamin.

\section{Response to insulin}

Alteration in the response to insulin occurred during the experiment. As deficiency progressed, the subject became resistant to insulin. Following the administration of thiamin, the response to the same dose of insulin was increased and when riboflavin was added insulin sensitivity developed (Table VI).

The 3 examinations made during the deficient period showed a progressive decrease, both in the percentage fall in blood sugar from the fasting level and in the symptomatic response to insulin. In the last test made during deficiency no fall in blood sugar occurred and the subject experienced no unusual symptoms. One week later, however, large doses of thiamin having been administered (Figure 1), a 36 per cent fall in blood sugar occurred and the subject experienced moderate symptoms of insulin shock after the test dose. During the remainder of the thiamin period the response to insulin appeared to vary roughly according to the amount of thiamin administered immediately prior to the test. When, however, riboflavin was added to a small dose of thiamin the
TABLE VI

Blood sugar, before and following the subcutaneous administration of 2.5 units of insulin in the different

experimental periods

\begin{tabular}{|c|c|c|c|c|c|c|c|}
\hline \multirow[b]{2}{*}{$\begin{array}{l}\text { Date } \\
1938\end{array}$} & \multicolumn{6}{|c|}{ Blood sugar } & \\
\hline & $\begin{array}{l}\text { Ini- } \\
\text { tial }\end{array}$ & hour & $\begin{array}{c}1 \\
\text { hour }\end{array}$ & $\begin{array}{c}2 \\
\text { hours }\end{array}$ & $\begin{array}{c}3 \\
\text { hours }\end{array}$ & $\begin{array}{c}\text { Max- } \\
\text { imal } \\
\text { de- } \\
\text { crease } \\
\text { in } \\
\text { blood } \\
\text { sugar* }\end{array}$ & \\
\hline March 11 & $\begin{array}{c}\text { mgm. } \\
\text { per } \\
100 \\
c c . \\
71\end{array}$ & $\begin{array}{c}\text { mgm. } \\
\text { per } \\
100 \\
c c . \\
66\end{array}$ & $\begin{array}{c}\text { mgm } \\
\text { per } \\
100 \\
c c . \\
56\end{array}$ & $\begin{array}{c}\text { mgm. } \\
\text { per } \\
100 \\
c c . \\
59\end{array}$ & $\begin{array}{c}\text { mgm. } \\
\text { per } \\
100 \\
c c . \\
61\end{array}$ & $\begin{array}{l}\text { per } \\
\text { cent } \\
21\end{array}$ & \multirow{3}{*}{$\begin{array}{l}\text { Deficient } \\
\text { diet }\end{array}$} \\
\hline March 25 & 70 & 70 & 63 & 68 & 78 & 10 & \\
\hline April 29 & 66 & 76 & 66 & 70 & 76 & 0 & \\
\hline May 6 & 77 & 53 & 49 & 56 & 62 & 36 & \multirow{3}{*}{$\begin{array}{l}\text { Deficient } \\
\text { diet } \\
\text { + thiamin }\end{array}$} \\
\hline May 13 & 66 & 64 & 65 & 65 & 66 & 3 & \\
\hline May 17 & 68 & 61 & 59 & 58 & & 15 & \\
\hline May 27 & 86 & 58 & 44 & 52 & 56 & 49 & \multirow{2}{*}{$\begin{array}{l}\text { Deficient } \\
\text { diet }+ \text { thi- } \\
\text { amin }+ \\
\text { riboflavin }\end{array}$} \\
\hline May 31 & 131 & 101 & 67 & 48 & 62 & 63 & \\
\hline
\end{tabular}

* Maximal decrease in blood sugar is here represented as the per cent fall from the initial blood sugar to the lowest value obtained in the test.

response was greater than that which had been obtained with thiamin alone. On May 27, when the subject was receiving daily 20 milligrams of thiamin and 6 milligrams of riboflavin, she experienced definite symptoms of shock following the standard dose of insulin, at which time a fall of 49 per cent in blood sugar occurred. These symptoms were transient and required no treatment, but on May 31, the test being repeated under identical conditions, the blood sugar fell 63 per cent and symptoms of reaction became severe, in spite of the high initial blood sugar.

Altered response to insulin has been reported in animals deficient in the $B$ complex, but the type of response appears to vary with the animal concerned. Rats deficient in the B complex (12) are reported sensitive to insulin while pancreatectomized dogs maintained on a B-deficient diet became resistant to insulin (29). Little assistance is obtained, therefore, from these animal experiments in interpretation of the changes observed in the human subject. 


\section{SUM MARY}

1. An otherwise normal individual, subsisting on a diet adequate except for the vitamin B complex, developed clinical manifestations and metabolic changes which responded in part to thiamin, were influenced only slightly by thiamin plus riboflavin and were relieved by the administration of brewer's yeast

2. In general, both clinical manifestations and metabolic changes were evident after 5 weeks on the experimental diet but did not become striking until the subject had consumed the deficient diet for 8 weeks.

3. Observations are presented showing the changes in fluid balance and body weight, in nitrogen excretion, in carbohydrate metabolism, and in the response to insulin.

4. Edema appeared early in deficiency, loss of body weight occurred late. Edema disappeared and normal body weight was maintained only following the administration of yeast.

5. The changes in carbohydrate metabolism included:

(a) Failure of the blood sugar to return to normal within 3 to 4 hours after the ingestion of glucose, this defect disappearing only after the administration of yeast. There was no evidence of failure to oxidize glucose as indicated by the respiratory quotient or of failure of absorption of glucose from the gastro-intestinal tract.

(b) There was no increase in the bisulphitebinding power or in the fasting pyruvic acid of the blood during deficiency. After the ingestion of glucose the pyruvic acid rose and remained high at 4 hours until after the administration of thiamin. Blood lactic acid was elevated during deficiency and returned to normal following the administration of thiamin.

(c) The respiratory quotient was unaltered during deficiency.

(d) The response to insulin decreased as deficiency progressed. There was an increased response to insulin following the administration of thiamin and, with the addition of riboflavin, the subject became sensitive to insulin.

We are indebted to Dr. D. Wright Wilson and to Dr. J. H. Jones of the Department of Physiological Chemistry for much advice and cooperation. We are indebted also to Dr. Herbert Fox in whose laboratory determinations of serum protein were carried out, and to Dr. L. G. Wesson who made several of the analyses for respiratory quotient.

\section{BIBLIOGRAPHY}

1. Peters, R. A., Biochemical lesion in $B_{1}$ deficiency; application of modern biochemical analysis in its diagnosis. Lancet, 1936, 1, 1161.

2. Peters, R. A., Pyruvate oxidase in brain; co-carboxylase. Biochem. J., 1937, 31, 2240.

3. Sherman, W. C., and Elvehjem, C. A., In vitro studies on lactic acid metabolism in tissues from polyneuritic chicks. Biochem. J., 1936, 30, 785.

4. Sherman, W. C., and Elvehjem, C. A., The effect of polyneuritis in chicks upon the in vivo rate of removal of pyruvate injection intravenously. $\mathrm{J}$. Nutrition, 1936, 12, 321.

5. Sherman, W. C., and Elvehjem, C. A., In vitro action of crystalline vitamin $B_{1}$ on pyruvic acid metabolism in tissues from polyneuritic chicks. Am. J. Physiol., 1936, 117, 142.

6. Thompson, R. H. S., and Johnson, R. E., Blood pyruvate in vitamin $B_{1}$ deficiency. Biochem. J., 1935, 29, 694.

7. Funk C., Action of substances influencing the carbohydrate metabolism in experimental beriberi. J. Physiol., 1919, 53, 247.

8. Drill, V. A., Effect of yeast on liver glycogen of white rats during hyperthyroidism. J. Nutrition, 1937, 14, 355.

9. Collazo, J. A., and Bayo, C. P., Uber die Wirkung der B-Vitamine und des Insulins auf die Kohlehydratstoffwechselstörungen bei Mangel an BVitaminen. Biochem. Ztschr., 1931, 238, 335.

10. Schroeder, H., Beziehungen der wichtigsten vitamine zum Kohlehydratstoff wechsel. Ztschr. f. d. ges. exper. Med., 1937, 101, 373.

11. Whipple, D. V., and Church, C. F., Effect of $B_{1}$ on the respiratory quotient. J. Biol. Chem., 1937, 119, liii (Proc.).

12. McIntyre, A. R., and Burke, J. C., Vitamin B. deficient diets and insulin tolerance in albino rats. Am. J. Physiol., 1937, 119, 364.

13. Muus, J., Bessey, O. A., and Hastings, A. B., Effect of lactoflavin and vitamin $B_{6}$ deficiency on tissue metabolism. J. Biol. Chem. 1937, 119, 1xxii (Proc.).

14. Elsom, K. O.; Experimental study of clinical vitamin B deficiency. J. Clin. Invest., 1935, 14, 40.

15. Cowgill, G. R., The vitamin B. requirement of man. Yale University Press, New Haven, 1934.

16. Folin, O., and Malmros, H., An improved form of Folin's micromethod for blood sugar determinations. J. Biol. Chem., 1929, 83, 115.

17. Evelyn, K. A., A stabilized photoelectric colorimeter with light filters. J. Biol. Chem., 1936, 115, 63.

18. Friedemann, T. E., and Graeser, J. B., The determination of lactic acid. J. Biol. Chem., 1933, 100, 291. 
19. Wendel, W. B., The determination of pyruvic acid and the preparation of lithium pyruvate. J. Biol. Chem., 1932, 94, 717.

20. Clift, F. P., and Cook, R. P., A method of determination of some biologically important aldehydes and ketones, with special reference to pyruvic acid and methylglyoxal. Biochem. J., 1932, 26, 1788.

21. Abbott, W. O., and Miller, T. G., Intubation studies of the human small intestine. III. A technique for the collection of pure intestinal secretion and for the study of intestinal absorption. J. A. M. A., 1936, 106, 16.

22. Groen, J., Absorption of glucose from small intestine in deficiency disease. New England J. Med., 1938, 218, 247.

23. Chambers, W. H., Undernutrition and carbohydrate metabolism. Physiol. Rev., 1938, 18, 248.

24. Conn, J. W., Newburgh, L. H., Johnston, M. W., and Sheldon, J. M., Study of the deranged carbohy- drate metabolism in chronic infectious hepatitis. Arch. Int. Med., 1938, 62, 765.

25. Vorhaus, M. G., Williams, R. R., and Waterman, R. E., Studies on crystalline vitamin $B_{1}$ : Observations in diabetes. Am. J. Digest. Dis. and Nutrition, 1935, 2, 541

26 Taylor, F. H. L., Weiss, S., and Wilkins, R. W., The bisulphite binding power of the blood in health and in disease with special reference to vitamin $\mathrm{B}_{1}$ deficiency J. Clin. Invest., 1937, 16, 833.

27. Platt, B. S., and Lu, C. G., Chemical and clinical findings in beriberi with special reference to vitamin $B_{1}$ deficiency. Quart. J. Med., 1936, 5, 355.

28. Lipschitz, M. A., Potter, V. R., and Elvehjem, C. A., The metabolism of pyruvic acid in vitamin $B_{1}$ deficiency and in inanition. J. Biol. Chem., 1937, 123, 267.

29. Martin R. W., Vitaminfreie Ernährung und Insulinwirksamkeit. Ztschr. f. physiol. Chem., 1937, 248, 242. 